\title{
Pengembangan Penilaian Autentik Berbasis Metode Penemuan Untuk Peningkatan Kemampuan Mahasiswa Dalam Mengassess Hasil Belajar
}

\author{
${ }^{1}$ Titi Laily Hajiriah, ${ }^{2}$ I Wayan Karmana, ${ }^{3}$ Iwan Doddy Dharmawibawa \\ 1,2,3 Program Studi Pendidikan Biologi FSTT UNDIKMA Mataram \\ Email : titilailyhajiriah@ikipmataram.ac.id
}

\begin{abstract}
Abstrak: tujuan dari pengembangan ini adalah untuk mengembangkan perangkat penilaian autentik berbasis penemuan untuk meningkatkan kemampuan mahasiswa dalam mengasses hasil belajar. Model pengembangan yang digunakan yaitu model 4D yang terdiri dari 4 tahapan yaitu define (pendefinisian), design (Perencanaan), develop (pengembangan), dan desimanate (penyebaran) . Tahap pengembangan instrumen perangkat penilaian autentik ini hanya sampai tahap pengembangan dengan teknik pengambilan data dengan mengevaluasi bahan ajar yang sudah dikembangkan ke beberapa validator dan mencari tingkat reliabilitasnya. Hasil penelitian ini menghasilkan instrumen perangkat penilaian autentik yang dikemas dalam bentuk bahan ajar dengan hasil validasi sebesar 3,59 dan nilai reliabilits sebesar 0,89 yang artinya perangkat instrumen yang sudah dikembangkan valid dan reliabel untuk digunakan oleh mahasiswa calon guru pendidikan biologi sebagai bahan ajar untuk mencontoh perangkat penilaian autentik berbasis penemuan.
\end{abstract}

Kata Kunci: Penilaian Autentik, metode penemuan, Hasil Belajar

Abstract: The purpose of this development is to develop an authentic discovery-based assessment tool to improve students' ability to assess learning outcomes. The development model used is the 4D model which consists of 4 stages, namely define, design, develop, and desimanate. The development stage of the authentic assessment instrument instrument is only up to the development stage with data collection techniques by evaluating the teaching materials that have been developed to several validators and looking for their level of reliability. The results of this study resulted in authentic assessment instruments packaged in the form of teaching materials with a validation result of 3.59 and a reliability value of 0.89 , which means that the instruments that have been developed are valid and reliable for use by prospective biology education teacher students as teaching materials for emulate authentic discovery-based assessment tools.

Keywords: Authentic Assessment, discovery method, Learning Outcomes

\section{LATAR BELAKANG}

Inovasi -inovasi pembelajaran berkembang dari masa ke masa. Inovasi yang muncul akibat dari perkembangan ilmu dan teknologi. Perubahan-perubahan yang diakibatkan secara langsung dan tidak langsung merubah wajah peradaban dunia terutama pada sector pendidikan yang memacu Sumber Daya Manusia (SDM) ikut serta memacu dirinya ke dalam perubahan tersebut. Berkaitan dengan pendidikan, tak terasa perubahan kurikulum sebagai bentuk perwujudan perkembangan ilmu mengantarkan kita terutama pendidikan di indinesia pada kurikulum 2013 untuk dipersiapkan pada era revolusi 4.0. Kompetensi yang diharapkan dalam penerapan kurikulum inipun sebanding dengan harapan bagimana peserta didik mampu menumbuh kembangkan kemampuannya baik secara kognitif, sosial, maupun psikomotoriknya yang tentu saja berimbas pada alat-alat ukur yang sepadan. Hal yang paling fundamental adalah mengubah pola pikir dan sifat peserta didik dalam mengembangkan kemampuannya dalam menghadapi revolusi industri 4.0 sehingga dapat menjadi sumber daya manusia yang unggul. 
Untuk itu, ada kecakapan yang harus dimiliki oleh setiap individu agar tetap bersaing dan diperhitungkan dalam kehidupan pada abad ke2, yaitu, (1) critical thinking and problem solving, (2) collaboration, (3) good communication, (4) creative and innovative thinking skill, (5) social responsibility, (6) work ethic. (Ike Sylvia, 2019)

Imbas dari revolusi pendidikan pun akan mempengaruhi pembelajaran di perguruan tinggi yang tentunya dilakukan secara terencana dan terpola untuk menciptakan suasana dan memberikan pelayanan agar mahasiswa belajar secara efektif. Bagi para dosen, tugas tama yang harus dilakukan adalah merencanakan dan melaksanakan serta penilaian yang bersifat komprensif (Siti Ermawati, 2017). Alat-alat ukur yang dipersiapkan harus berimbang sebagai bentuk perwujudan lapran kemajuan peserta didik dikemas dalam bentuk Penilaian autentik (Authentic Assessment) . Penilaian autentik ini bertujuan untuk mengukur hasil belajar peserta didik untuk ranah sikap, keterampilan, dan pengetahuan yang baik dan benar. Terkait dengan penilaian autentik, penelitian ini mengemas intrumen-instrumen penilaiannya dengan mengintegrasikan ke desain pembelajaran penemuan.

Fokus penilaian autentik cenderung mengarah pada tugas-tugas kompleks atau kontekstual, sehingga memungkinkan peserta didik untuk mampu menunjukkan kompetensi mereka dalam pengaturan yang lebih autentik. Penilaian autentik sebagai kegiatan menilai peserta didik yang menekankan pada apa yang seharusnya dinilai, baik proses maupun hasil dengan berbagai instrumen penilaian yang disesuaikan dengan tuntutan kompetensi (Kunandar,2013). Tujuan dari penilaian autentik adalah untuk memberikan informasi yang valid dan akurat tentang apa yang diketahui serta dapat dilakukan oleh peserta didik (Mundilarto, 2010).

Peningkatan kualitas pendidikan memerlukan perbaikan proses pembelajaran di sekolah dengan menerapkan cara kerja sistematis, salah satu diantaranya dapat dimulai dari pembenahan sistem asesmen (penilaian). Pendapat ini mengandung makna bahwa untuk memperbaiki sistem pembelajaran di sekolah, diperlukan sejumlah informasi dari hasil kegiatan asesmen yang dilakukan secara sistematis dan profesional oleh guru, sekolah, maupun institusi pendidikan yang lain (Hangstum, (2006), dalam (Ike Sylvia, 2019) ).

Beberapa fakta real di lapangan yang menjadi alasan yang sangat perlu diperhatikan adalah (1) tidak semua guru lulusan pendidikan; (2) mahasiswa-mahasiswi calon guru tidak semua terampil dalam penilai hasil belajar; (3) masih ada guru yang belum memahami secara fasih tentang penilaian autentik. Yang perlu diperhatikan lagi adalah proses penilaian autentik ini tidak menjadi fokus dalam penilaian karena hanya menyorot perubahan hasil belajar kognitif terlebih lagi penyusunan rubrik dalam penilaian autentik sering terjadi kekeliruan.

Sebagai langkah awal atas kelemahankelamahan dalam penilaian autentik ini terutama yang ditekankan adalah mahaiswa calon guru untuk dilatih secara discovering untuk meningkatkan kemampuan mereka dalam mengasses hasil belajar diperlukan media berupa bahan ajar yang dapat membantu mereka.

Berdasarkan paparan tersebut sangat diharapkan tersusunnya bahan ajar yang mendeskripsikan proses dan tata cara penilaian autentik. Konsep metode penemuan yang diintegrasikan pada bahan ajar ini bertujuan untuk memberi kesempatan penggunanya untuk mengekplore kemampuan mereka dalam penilaian.Sehingga dengan adanya bahan ajar penilaian autentik berbasis metode penemuan ini dapat memberi efek dalam peningkatan kemampuan mahasiswa calon guru dalam mengassess hasil belajar. penilaian autentik berbasis metode penemuan untuk melatih kemampuan mahasiswa dalam mengassess hasil belajar. Bahan ajar yang dikembangkan nantinya akan digunakan sebagai acuan, refrensi bagi mahasiswa calon guru atau para guru untuk meningkatkan kemampuan mereka dalam mengasess hasil belajar. 
Jurnal Ilmu Sosial dan Pendidikan

http://ejournal.mandalanursa.org/index.php/JISIP/index

Terakreditasi Peringkat 5 (No. SK: 85/M/KPT/2020)

\section{METODE PENELITIAN}

Pada bagian ini akan di bahas mengenai rencana penelitian yang meliputi pendekatan penelitian, teknik pengumpulan data,teknik analisis data dan induksi hasil penelitian.

\section{Pendekatan Penelitian}

Jenis penelitian yang digunakan dalam penelitian ini merupakan penelitian pengembangan (Research and Development).Model pengembangan yang digunakan dalam penelitian ini mengadopsi tiga dari empat tahap pengembangan yang dikembangkan oleh Sivasailam Thiagarajan (dalam Habibi, 2014).Model pengembangan ini meliputi tahap Define (Pendefinisian), Design (Perancangan), Develop (Pengembangan), dan Disseminate (Penyebarluasan).Pada tahap Define dilakukan studi pendahuluan yang terdiri dari analisis kebutuhan, analisis materi, dan analisis tujuan pengembangan.Tahap Design dilakukan untuk menetapkan format pembuatan bahan ajar sesuai dengan yang telah distandardkan sehingga menghasilkan Draft I. Tahap Develop dilakukan untuk menghasilkan Draft II, Draft III dan produk akhir bahan ajar yang dikembangkan.

\section{Teknik Pengumpulan Data}

Setelah bahan ajar selesai dibuat maka dilakukan uji coba validasi dan reliabilitas produk sampai dirasakan cukup memuaskan dan bisa dipergunakan.

\section{Teknik Analisis Data}

Data yang dikumpulkan melalui penelitian ini berupa data tentang: (1) kemenarikan bahan ajar; (2) relevansi bahan yang dipelajari; (3) tingkat kebermanfaatan bahan ajar; (4) kesesuaian bahan yang dipelajari.

Data yang diperoleh dianalisis secara deskriptif, dimana data hasil telaah tersebut diuraikan dengan kalimat yang jelas sehingga bernilai sesuai dengan pedoman deskripsi skor validasi perangkat pada tabel 3.1, yang diadaptasi dari Ratumanan dan Laurens (2006):
Vol. 4. No. 4 November 2020

p-ISSN: 2598-9944 e- ISSN: 2656-6753

Tabel 1 Deskripsi Skor Validasi Bahan Ajar
\begin{tabular}{|l|l|l|}
\hline Skor interval & Kategori & \multicolumn{1}{|c|}{ Keterangan } \\
\hline $1,0-1,5$ & $\begin{array}{l}\text { Tidak dapat } \\
\text { baik } \\
\text { digunakan dan } \\
\text { masih } \\
\text { memerlukan } \\
\text { konsultasi }\end{array}$ \\
\hline $1,6-2,5$ & $\begin{array}{l}\text { Kurang } \\
\text { baik }\end{array}$ & $\begin{array}{l}\text { Dapat digunakan } \\
\text { dengan banyak } \\
\text { revisi }\end{array}$ \\
\hline $2,6-3,5$ & Baik & $\begin{array}{l}\text { Dapat digunakan } \\
\text { dengan sedikit } \\
\text { revisi }\end{array}$ \\
\hline $3,6-4,0$ & $\begin{array}{l}\text { Sangat } \\
\text { baik }\end{array}$ & $\begin{array}{l}\text { Dapat digunakan } \\
\text { tanpa revisi }\end{array}$ \\
\hline
\end{tabular}

Bahan ajar dikatakan efektif untuk dilakukan uji coba jika rata-rata skor tiap perangkat pembelajaran mempunyai kategori baik (Sukarjo, 2005).Untuk mendapatkan rerata dari seluruh validator dapat dideskripsikan dengan membagi skor tiap aspek dengan skor maksimum kemudian mengalikannya dengan $100 \%$. Deskrispi rerata skor validator menurut Riduwan (2006), dapat di interpretasikan dengan rentang persentase sebagai berikut:

Tabel 2. Deskripsi Skor Validasi Bahan

Ajar

\begin{tabular}{|l|l|}
\hline \multicolumn{1}{|c|}{ Persentase } & \multicolumn{1}{c|}{ Kategori } \\
\hline $81 \%-100 \%$ & Sangat baik \\
\hline $61 \%-80 \%$ & Baik \\
\hline $41 \%-60 \%$ & Kurang Baik \\
\hline$<41 \%$ & Tidak baik \\
\hline
\end{tabular}

\section{HASIL PENELITIAN}

Pengembangan yang dilakukan meliputi 3 aspek kompetensi yang berkaitan dengan penilaian autentik yang diintegrasikan ke dalam sintaks pembelajaran penemuan (discovery learning). Adapun contoh instrumen yang telah dikembangkan dan tertera dalam bahan ajar dapat diliat sebagai berikut :

Tabel 3. Aspek Kompetensi penilaian autentik yang dikembangkan dalam bahan ajar 


\begin{tabular}{|l|l|l|l|}
\hline \multicolumn{1}{|c|}{$\begin{array}{c}\text { Aspek } \\
\text { kompetensi }\end{array}$} & \multicolumn{1}{|c|}{$\begin{array}{l}\text { Sasaran } \\
\text { penilaian }\end{array}$} & $\begin{array}{l}\text { Teknik } \\
\text { penilaian }\end{array}$ & $\begin{array}{l}\text { Bentuk } \\
\text { penilaian }\end{array}$ \\
\hline 1. Menanggapi & $\begin{array}{l}\text { 2. Nilai Mengatur } \\
\text { 3. Menilaian diri } \\
\text { (self } \\
\text { assessment })\end{array}$ & $\begin{array}{l}\text { Kuesioner } \\
\text { (rating scale })\end{array}$ \\
\hline $\begin{array}{l}\text { Keterampingintahuan } \\
\text { abstrak }\end{array}$ & $\begin{array}{l}\text { 1. Mengamati } \\
\text { 2. Mengolah } \\
\text { 3. Menyaji } \\
\text { 4. Menalar }\end{array}$ & Unjuk kerja & Rating scale \\
\hline $\begin{array}{l}\text { Keterampilan } \\
\text { konkret }\end{array}$ & $\begin{array}{l}\text { 1. Persepsi } \\
\text { 2. Mesiapan Meniru } \\
\text { 3. Membiasakan menjadi tindakan orisinal }\end{array}$ & Unjuk kerja & Rating scale \\
\hline
\end{tabular}

Tabel 4. Contoh Penilaian Autentik terhadap Keterampilan Abstrak Siswa dalam Pembelajaran Berbasis Penemuan

\begin{tabular}{|c|c|c|}
\hline $\begin{array}{c}\text { Aspek } \\
\text { sikap yang } \\
\text { diamati }\end{array}$ & $\begin{array}{l}\text { Skor yang } \\
\text { diperoleh }\end{array}$ & $\begin{array}{c}\text { Rubrik } \\
\text { penskoran }\end{array}$ \\
\hline Mengamati & & $\begin{array}{l}\text { Aspek } \\
\text { Mengamati }\end{array}$ \\
\hline Mengolah & & $\begin{array}{l}\text { Skor } 4 \text { : apabila } \\
\text { siswa mampu }\end{array}$ \\
\hline Menyaji & & $\begin{array}{l}\text { merespon } \\
\text { perubahan yang }\end{array}$ \\
\hline menalar & & $\begin{array}{l}\text { terjadi } \\
\text { proses }\end{array}$ \\
\hline Total skor & & pengamatan \\
\hline $\begin{array}{c}\text { Kriteria } \\
\text { sikap siswa }\end{array}$ & & $\begin{array}{l}\text { secara mandiri } \\
\text { dan tepat konsep. } \\
\text { Skor } 3 \text { : apabila } \\
\text { siswa mampu } \\
\text { merespon } \\
\text { perubahan yang } \\
\text { terjadi pada } \\
\text { proses } \\
\text { pengamatan } \\
\text { secara mandiri } \\
\text { dan tepat konsep } \\
\text { setelah melalui } \\
\text { penjelasan dari } \\
\text { guru sebelumnya. } \\
\text { Skor } 2 \text { : apabila } \\
\text { siswa kurang } \\
\text { mampu merespon } \\
\text { perubahan yang } \\
\text { terjadi pada } \\
\text { proses pengamatan } \\
\text { melaui } \\
\text { pembimbingan }\end{array}$ \\
\hline
\end{tabular}

\begin{tabular}{|c|c|c|}
\hline $\begin{array}{c}\text { Aspek } \\
\text { sikap yang } \\
\text { diamati }\end{array}$ & $\begin{array}{l}\text { Skor yang } \\
\text { diperoleh }\end{array}$ & $\begin{array}{c}\text { Rubrik } \\
\text { penskoran }\end{array}$ \\
\hline & & $\begin{array}{l}\text { secara langsung } \\
\text { tetapi tepat } \\
\text { konsep setelah } \\
\text { melalui } \\
\text { penjelasan dari } \\
\text { guru sebelumnya. } \\
\text { Skor } 1 \text { : apabila } \\
\text { siswa tidak } \\
\text { mampu merespon } \\
\text { perubahan yang } \\
\text { terjadi pada } \\
\text { proses } \\
\text { pengamatan } \\
\text { meskipun melaui } \\
\text { pembimbingan } \\
\text { secara langsung } \\
\text { guru sebelumnya } \\
\text { Aspek Mengolah } \\
\text { Skor } 4 \text { : apabila } \\
\text { siswa mampu } \\
\text { mengolah data } \\
\text { dan informasi } \\
\text { yang terjadi pada } \\
\text { proses } \\
\text { pengambilan } \\
\text { kesimpulan } \\
\text { secara mandiri } \\
\text { dan tepat konsep. } \\
\text { Skor } 3 \text { : apabila } \\
\text { siswa mampu } \\
\text { mengolah data } \\
\text { dan informasi } \\
\text { yang terjadi pada } \\
\text { proses } \\
\text { pengambilan } \\
\text { kesimpulan } \\
\text { secara mandiri } \\
\text { dan tepat konsep } \\
\text { setelah melalui } \\
\text { penjelasan dari } \\
\text { guru sebelumnya. } \\
\text { Skor } 2 \text { apabila } \\
\text { siswa kurang }\end{array}$ \\
\hline
\end{tabular}




\begin{tabular}{|c|c|c|c|c|c|}
\hline $\begin{array}{c}\text { Aspek } \\
\text { sikap yang } \\
\text { diamati } \\
\end{array}$ & $\begin{array}{l}\text { Skor yang } \\
\text { diperoleh }\end{array}$ & $\begin{array}{c}\text { Rubrik } \\
\text { penskoran }\end{array}$ & $\begin{array}{c}\text { Aspek } \\
\text { sikap yang } \\
\text { diamati } \\
\end{array}$ & $\begin{array}{l}\text { Skor yang } \\
\text { diperoleh }\end{array}$ & $\begin{array}{c}\text { Rubrik } \\
\text { penskoran }\end{array}$ \\
\hline & & 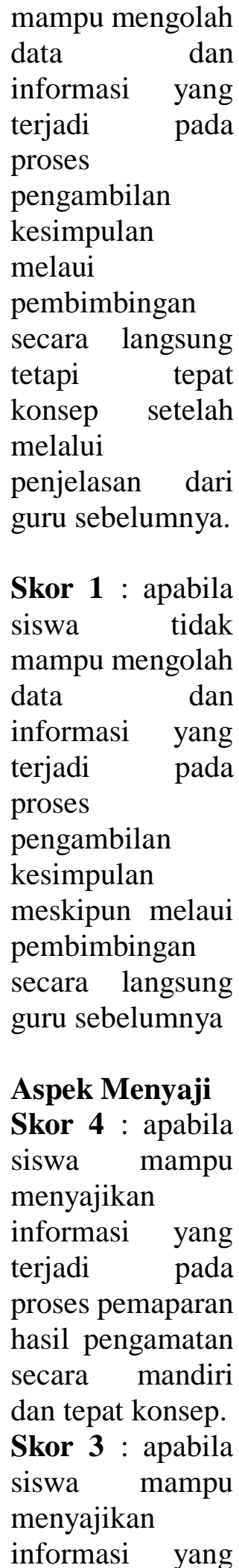 & & & $\begin{array}{l}\text { terjadi pada } \\
\text { proses pemaparan } \\
\text { hasil pengamatan } \\
\text { secara mandiri } \\
\text { dan tepat konsep } \\
\text { setelah melalui } \\
\text { penjelasan dari } \\
\text { guru sebelumnya. } \\
\text { Skor } 2 \text { : apabila } \\
\text { siswa kurang } \\
\text { mampu } \\
\text { menyajikan } \\
\text { informasi yang } \\
\text { terjadi prada } \\
\text { proses pemaparan } \\
\text { hasil pengamatan } \\
\text { melaui } \\
\text { pembimbingan } \\
\text { secara langsung } \\
\text { tetapi tepat } \\
\text { konsep setelah } \\
\text { melalui } \\
\text { penjelasan dari } \\
\text { guru sebelumnya. } \\
\text { Skor } 1 \text { : apabila } \\
\text { siswa tidak } \\
\text { mampu } \\
\text { menyajikan } \\
\text { informasi yang } \\
\text { terjadi pada } \\
\text { proses pemaparan } \\
\text { hasil pengamatan } \\
\text { meskipun melaui } \\
\text { pembimbingan } \\
\text { secara langsung } \\
\text { guru sebelumnya } \\
\text { Aspek Menalar } \\
\text { Skor } 4 \text { : apabila } \\
\text { siswa mampu } \\
\text { menalar } \\
\text { fenomena antara } \\
\text { hasil pengamatan }\end{array}$ \\
\hline
\end{tabular}




\begin{tabular}{|c|c|c|}
\hline $\begin{array}{c}\text { Aspek } \\
\text { sikap yang } \\
\text { diamati }\end{array}$ & $\begin{array}{l}\text { Skor yang } \\
\text { diperoleh }\end{array}$ & $\begin{array}{c}\text { Rubrik } \\
\text { penskoran }\end{array}$ \\
\hline & & 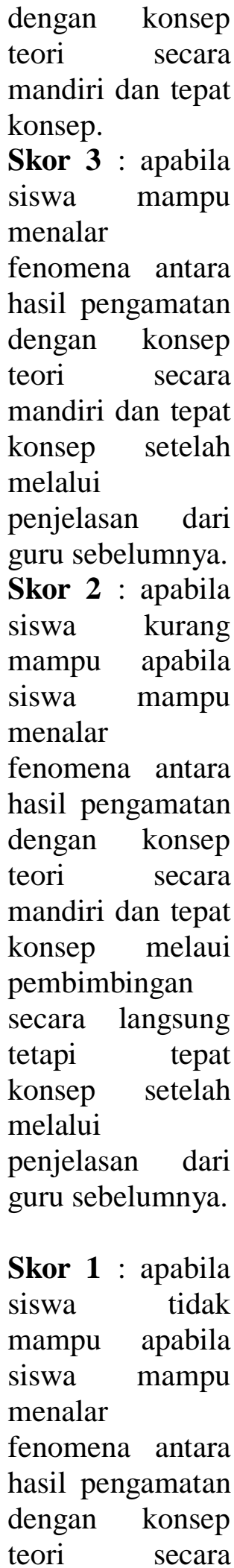 \\
\hline
\end{tabular}

\begin{tabular}{|l|l|l|}
\hline $\begin{array}{c}\text { Aspek } \\
\text { sikap yang } \\
\text { diamati }\end{array}$ & $\begin{array}{l}\text { Skor yang } \\
\text { diperoleh }\end{array}$ & \multicolumn{1}{|c|}{$\begin{array}{c}\text { Rubrik } \\
\text { penskoran }\end{array}$} \\
\hline & & $\begin{array}{l}\text { mandiri dan tepat } \\
\text { konsep meskipun } \\
\text { melaui } \\
\text { pembimbingan } \\
\text { secara langsung } \\
\text { guru sebelumnya }\end{array}$ \\
\hline
\end{tabular}

\section{Rubrik penilaian kriteris keterampilan} abstrak siswa

Total skor $>4$ : kurang aktif

Total skor 5-9 : cukup aktif

Total skor $10-14 \quad$ : aktif

Total skor $>15$ : sangat aktif

Hasil pengembangan bahan ajar yang berisi tentang pengembangan intrumen penilaian autentik berbasi penemuan ini kemudian divalidasi oleh 5 validator yang terdiri dari 3 orang mahasiswa program studi pendidikan biologi semester 7 Tahun Akademik 2020/2021 dan 2 orang dosen program studi pendidikan biologi Fakultas Sains, Teknik dan Terapan Universitas Pendidikan Mandalika Mataram., adapun hasil validasinya tertera pada tabel di bawah ini:

Tabel 5. Hasil Validasi bahan ajar yang dikembangkan

\begin{tabular}{|c|l|c|c|c|c|c|}
\hline \multirow{2}{*}{ No } & \multicolumn{1}{|c|}{ Pertanyaan } & \multicolumn{5}{|c|}{ Validator (V) ke - } \\
\cline { 2 - 7 } & $\mathbf{V}_{\mathbf{1}}$ & $\mathbf{V}_{\mathbf{2}}$ & $\mathbf{V}_{\mathbf{3}}$ & $\mathbf{V}_{\mathbf{4}}$ & $\mathbf{V}_{\mathbf{5}}$ \\
\hline 1. & Designnya menarik & 3 & 3 & 3 & 3 & 3 \\
\hline 2. & $\begin{array}{l}\text { Isi dari Bahan Ajar menarik dan mudah } \\
\text { dimengerti }\end{array}$ & 4 & 4 & 4 & 3 & 3 \\
\hline 3. & $\begin{array}{l}\text { Contoh yang dikembangkan dalam buku ajar } \\
\text { mudah dimengerti }\end{array}$ & 4 & 4 & 4 & 4 & 4 \\
\hline 4. & $\begin{array}{l}\text { Tidak ada kalimat yang sulit dimengerti baik } \\
\text { dalam Buku ajar }\end{array}$ & 3 & 3 & 3 & 3 & 4 \\
\hline 5 & $\begin{array}{l}\text { Relevansi bahan ajar yang dipelajari sangat } \\
\text { baik }\end{array}$ & 3 & 3 & 3 & 3 & 3 \\
\hline 6 & Terdapat kebermanfatan dari isi bahan ajar & 4 & 4 & 4 & 4 & 3 \\
\hline 7 & $\begin{array}{l}\text { Isi bahan ajar sesuai dengan materi yang } \\
\text { dipelajari }\end{array}$ & 4 & 4 & 3 & 4 & 3 \\
\hline & Jumlah & 25 & 25 & 24 & 25 & 23 \\
\hline & Rata-rata per validator & 3.75 & 3.75 & 3.42 & 3.75 & 3.28 \\
\hline & Rata-rata semua validator & \multicolumn{5}{|c|}{3.59} \\
\hline & Kategori & \multicolumn{5}{|c|}{ Baik } \\
\hline
\end{tabular}

Berdasarkan Tabel di atas, hsil analisis datanya setelah dikonversi ke dalam Tabel 1 dan Tabel 2 dapat disimpulkan bahwa bahan ajar yang dihasilkan dari pengembangan penelitian ini adalah valid dan baik digunakan sebagai 
bahan ajar dikalangan mahasiswa calon guru pendidikan biologi.

Hasil reliabilitas pengembangan instrumen penilaian autentik berbasis penemuan tahap implementasi menunjukkan rata-rata nilai alpha sebesar 0,89 . Hal tersebut menunjukkan bahwa pengembangan instrumen penilaian autentik berbasis penemuan pada tahap implementasi dinyatakan reliabel.

\section{PEMBAHASAN}

Beberapa penelitian serupa yang melakukan pengembangan penilaian autentik seperti (Nino Nurjananto, 2015), (Ike Sylvia, 2019), (Siti Ermawati, 2017), sependapat untuk menyimpulkan pada proses penilaian diperlukan instrumen penilaian yang dapat mengukur semua aspek kompetensi peserta didik yang menuntut peserta didik untuk aktif, salah satunya dengan menerapkan penilaian autentik dan sangat perlu melakukan perubahan-perubahan terhadap intrumen penilaian autentik demi mempermudah proses penilaian terutama terkait dengan hasil belajar. Pierce dan O'Malley (1996) dalam (Sukardi, 2008),mengatakan bahwa asesmen otentik mimiliki enam karateristik:

1. Constructed response:

siswa mengkonstruksi sebuah respon, memberikan respon meluas, terlibat dalam kinerja, atau menciptakan sebuah produk.

2. Higher-order Thinking: siswa secara tipikal menggunakan pemikiran tingkat tinggi dalam mengkonstruksi respon terhadap pertanyaan terbuka.

3. Authenticity: tugas-tugas bermakna, menantang dan aktivitas pembelajaran yang mencerminkan pembelajaran yang baik atau konteks dunia nyata lainnya dimana nantinya siswa diharapkan dapat melakukannya.

4. Integrative: tugas-tugas harus mengintegrasikan semua keterampilan, dan dalam beberapa hal, menyangkut integrasi pengetahuan serta keterampilanketerampilan lintas isi.
5. Process and Product: prosedur dan strategi yang dipergunakan untuk mencari dan mendapatkan jawaban yang benar atau untuk mengeksplorasi beragam solusi dari tugas-tugas yang kompleks sering dinilai dan begitu juga produknya yang berupa jawaban yang benar.

6. Depth Versus Breadth: memberikan informasi yang mendalam tentang ketrampilan seorang siswa atau belajar tutas (mastery learning) seperti dikontraskan dengan tes pilihan ganda dengan cakupan yang luas tetapi kurang dapat melatih ketrampilan berfikir atau daya nalar tingkat tinggi.

Terkait dengan penelitian pengembangan ini dengan menghasilkan bahan ajar sebagai panduan untuk menyusun instrument penilaian autentik berbasis penemuan dapat meningkatkan kemampuan mahasiswa dalam mengasses hasil belajar. Adapun harapan dari tersusunnya instrumen penilaian autentik berbasis penemuan ini selain mampu meningkatkan kemampuan mahasiswa dalam mengasses hasil belajar tentunya dapat membantu mahasiswa mengulang apa yang telah dipelajari karena hal demikian hanyalah melatih mereka menghafal dan mengingat saja yang kurang bermakna. Melalui pengembangan intrumen penilaian autentik berbasis penemuan mahasiswa diminta untuk mengkonstruksikan apa yang telah diperoleh ketika mereka dihadapkan pada situasi konkret khususnya yang terintegrasi dengan model pembelajaran penemuan.

Adapun beberapa kendala dalam penelitian ini adalah pertama kurangnya contoh dari literatur yang membahas tentang teknik dan prosedur penilaian autentik, kedua kesediaan mahasiswa sebagai validator yang memang ketika diminta sebagai validator memiliki kegiatan yang padat terkait perkuliahan yang secara online dengan berbagai tugas yang harus dikerjakan segera, ketiga koordinasi yang memang perlu dilakukan secara matang antara peneliti dan validator. Dari ketiga kendala yang memang sangat perlu dibenahi adalah proses 
mencari contoh instrumen pengembangan penilaian autentik yang tepat sesuai judul penelitian ini sehinga inisiatifnya adalah dengan mendesain sendiri instrumen penilaian autentik berbasis penemuan yang sesui dengan tujuannya.

\section{SIMPULAN}

Hasil pengembangan instrumen penilaian autentik berbasis penemuan ini berdasarkan hasil validasi dari beberapa validator dikatakan valid dan layak digunakan sebagai contoh instrumen penilaian dengan nilai keabsahan 3,59 serta nilai reliabilitas sebsas 0,89 yang artinya perangkat instrumen yang sudah dikembangkan reliabel untuk digunakan oleh mahasiswa calon guru pendidikan biologi.

\section{SARAN}

Untuk keberlanjutan dari pengembangan instrumen penilaian autentik berbasis penemuan untuk meningkatkan kemampuan mahasiswa dalam mengasses hasil belajar perlu dilakukan ujicoba produk yang lebih luas untuk memperoleh kebermanfaatan bahan ajar ini baik dari segi pemahaman mahasiswa calon guru pendidikan biologi dalam mengasses hasil belajar sesuai dengan pengintegrasiaannya dalam model pembelajaran maupun untuk melihat kekurangan dan kelebihan instrument tersebut sebagai bahan ajar.

\section{DAFTAR RUJUKAN}

Dimyati dan Mudjiono, 2009.Belajar dan Pembelajaran. Jakarta: Rineka Cipta.

Habibi dan Susilawati. 2014. Pengembangan Buku Ajar Astronomi Berbasis Self Regulated Learning Sebagai Upaya Memotivasi Mahasiswa untuk Belajar Mandiri. Prosiding Seminar Nasional FPMIPA IKIP Mataram.

Ibrahim, Muslimin, 2012. Assessmen Berkelanjutan. Surabaya. UNESA Press Indah Nurcahyani,Eko Setyadi Kurniawan dan Sriyono, (2012). Pengembangan Penilaian Autentik guna mengukur Pengetahuan dan Kreativitas dalam
Pembelajaran Fisika pada peserta didik SMA Negeri 6 Purworejo. Jurnal Radiasi Vol.3, No.1 2012, hlm 37-41 prodi pendidikan fisika Universitas Muhammadiyah Purworejo

Laily H, 2014.Pengintegrasian Self Assessment dan Peer Review melalui PembelajaranKooperatif Tipe NHT. Prosiding Seminar Nasional FPMIPA IKIP Mataram 22 November 2014

Laily H, 2014.Korelasi Hasil Belajar Siswa MelaluiPengembangan Perangkat Penilaian Peer Review dan Self Assessment pada Penerapan Model Cooperative TipeNumbered Head Together. Jurnal Bioscientist Hal 288-298, vol 2, No.2 Desember 2014, ISSN 23385006

Ike Sylvia, S. A. (2019). Pengembangan Instrumen Penilaian Autentik Berbasis Pendekatan Authentic Inquiry. Journal of Sociology Research and Education, Vol.6, No.2, Th. 2019, 103-120.

Nino Nurjananto, E. K. (2015).

PENGEMBANGAN INSTRUMEN PENILAIAN AUTENTIK UNTUK MENGUKUR KOMPETENSI PESERTA DIDIK MATERI SENYAWA HIDROKARBON. Jurnal Inovasi Pendidikan Kimia, Vol 9, No. 2, 2015, 1575 - 1584.

Ratumanan dan Laurens (2004). Belajar dan Pembelajaran edisi ke-2. Surabaya: UNESA University Press.

Siti Ermawati, T. H. (2017). PENILAIAN

AUTENTIK DAN RELEVANSINYA

DENGAN KUALITAS HASIL PEMBELAJARAN (PERSEPSI DOSEN DAN MAHASISWA IKIP PGRI BOJONEGORO). Jurnal Pendidikan Ilmu Sosial, Vol 27, No.1, Juni 2017, 92-103.

Sukardi. (2008). Evaluasi Pendidikan Prinsip dan Operasionalnya. Jakarta: Bumi Aksara. 
Setyosari, Punaji. 2013. Metode Penelitian

Pendidikan dan Pengembangan. Jakarta:

Penerbit Kencana.

Sukarjo. (2005). EValuasi Pembelajaran:

Diktat Mata Kuliah Program Studi

Teknologi Pembelajaran. Yogyakarta:

Tidak dipublikasikan

Susilawati, 2014.Pengaruh Penggunaan

Bukuajar Terhadap Hasil Belajar Pada

Matakuliah Pendahuluan Fisika Inti

Ditinjau Dari Motivasi Belajar.Prosiding

Seminar Nasional FPMIPA IKIP

Mataram. 